Uluslararası Sosyal Bilgilerde Yeni Yaklaşımlar Dergisi, 2021, 5(1), 256-277

International Journal of New Approaches in Social Studies, 2021, 5(1), 256-277

\title{
Sosyal Bilgiler Öğretmen Adaylarının Bilimsel Araştırma ve Bilim Ínsanına Yönelik Metaforik Algıları*
}

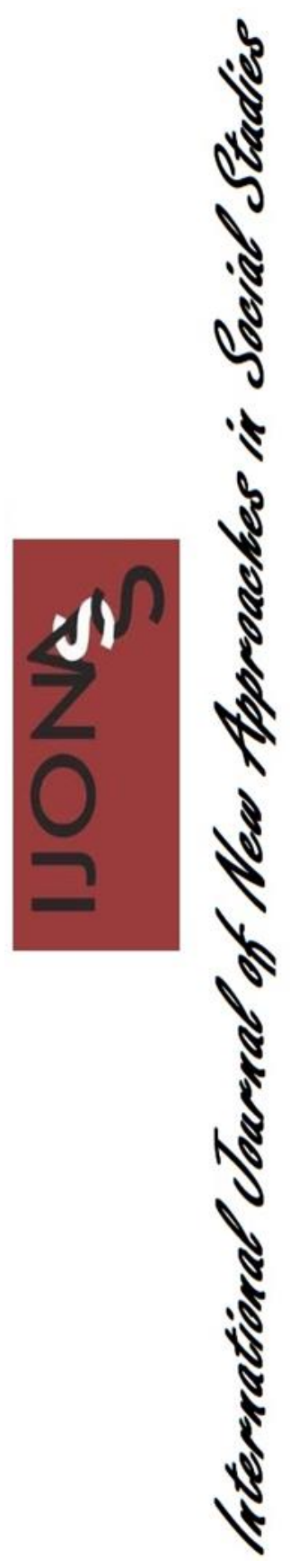

\author{
Tuğçe SEMİ ${ }^{1}$ (D) \& Canan TUNÇ ŞAHIN ${ }^{2 * *}$ (D)
}

Gönderilme Tarihi: 10 Mayıs 2021

Kabul Tarihi: 16 Haziran 2021

DOI: $10.38015 /$ sbyy. 930082

$\ddot{O}_{z:}$

Araştırma sosyal bilgiler ögretmen adaylarının bilimsel araştırma ve bilim insanına yönelik metaforik algılarını belirlemek amacıyla nitel araștırma yaklaşımlarından olgu bilim araştırma deseni kullanılarak gerçekleştirilmiştir. Araştırma sosyal bilgiler öğretmenliği bölümünde öğrenim gören 1., 2., 3. ve 4. sinıf öğrencileri (145 kişi) ile yapılmıştır. Veri toplama aracı olarak birinci kısmında katılımciların demografik değişkenleri belirlemeye yönelik sorulara, ikinci kusminda ise "Bilimsel araştırma... gibidir, çünkü ...." ve "Bilim insant...... gibidir, çünkü ......" cümle kalıbına yer verilen yarı yapılandırllmış form ve Chambers (1983) tarafindan geliştirilen 'Bir Bilim İnsanı Çiz Testi' kullanılmıştır. Araştırma bulgular olarak sosyal bilgiler ögretmen adaylarının "bilimsel araştırma" kavramına yönelik yöntem, bilimin doğası özellikleri ve yanılgılar kategorilerinde, "bilim insanı" kavramina yönelik kişisel özellikler, mesleki özellikler, çalışma ortamı ve kullandığı araçlar ve model bilim insanı olmak üzere 7 farklı kategori altına yerleştirilen 227 farklı metafor oluşturduğu saptanmıştır. Araştırma sonuçlarına göre öğretmen adaylarının bilimsel araştırma kavramına yönelik algıları yöntem, bilimin doğası özellikleri ve yanılgılardır. Öğretmen adayları bilimin doğasına yönelik bazı kavram yanılgılarına sahiptir. Öğretmen adaylarının bilimsel araştırmayla ilgili kavram yanılgilarının giderilmesine yönelik öğretmen eğitimi kapsamında bilimsel araştırma, bilimin işleyişi, bilimin doğasının etkili şekilde ögretilmesini amaçlayan derslerin programda yer alması gerekir. Bilim insanı kavramina yönelik algıları ise kişisel özellikleri, mesleki özellikleri, çalışma ortamı ve kullandığ araçlara yönelik algılar olarak tespit edilmiş̧tir. Öğretmen adayları bilim insanının sahip olduğu özellikleri deney yapan, laboratuvarda çalışan, sorgulayan, problem çözen, topluma yol gösteren bireyler olarak algilamaktadırlar.

Anahtar Kelimeler: Bilimsel okuryazarlık, bilimsel araştırma, bilim insanı, metaforik algl.

\begin{abstract}
:
The study was carried out using phenomenology research design, one of the qualitative research approaches, in order to determine the metaphorical perceptions of social studies teacher candidates on scientific research and scientists. The study was carried out with year 1,2,3 and 4 students (145 students) studying in the department of social studies teaching. As a data collection tool, in the first part, the questions about determining the demographic characteristics of the participants, in the second part, sentence patterns such as "Scientific research is like... because...." and "Scientist is like ......, because ......" in the semi-structured form and the "Draw-A-Scientist Test"
\end{abstract}

\footnotetext{
1Zonguldak Bülent Ecevit Üniversitesi, Türkiye, ORCID ID: 0000-0002-4127-5137

${ }^{2}$ Zonguldak Bülent Ecevit Üniversitesi, Türkiye, ORCID ID: 0000-0003-0997-2124

*Bu makale, Zonguldak Bülent Ecevit Üniversitesi Sosyal Bilimler Enstitüsü tarafından kabul edilen birinci yazara ait "Sosyal bilgiler ögretmen adaylarının bilimsel araştırma ve bilim insanına yönelik metaforik algıları" isimli yüksek lisans tezinden üretilmiștir.

${ }^{* *}$ SorumluYazar (Corresponding Author): canantuncsahin@gmail.com
} 
developed by Chambers (1983) were used. As research findings, social studies teacher candidates were found to form a total of 227 different metaphors under seven different categories: Method, characteristics of the nature of science, and misconceptions for the concept of "scientific research" personal characteristics, occupational characteristics, occupational environment and tools used, and model scientist for the concept of "scientist". According to the results of the study, the perceptions of the teacher candidates on the concept of scientific research were methods, characteristics of the nature of science, and errors. Teacher candidates have some misconceptions about the nature of science. Within the scope of teacher training aimed at eliminating the teacher candidates' misconceptions about scientific research, the courses aimed at effectively teaching scientific research, the processes of science, and the nature of science should be included in the curriculum. Their perceptions of the scientist concept were determined to be personal characteristics, occupational characteristics, occupational environment, and tools they use. Teacher candidates perceive the characteristics of scientists as individuals who conduct experiments, work in laboratories, question, solve problems, and guide society.

Keywords: Scientific literacy, scientific research, scientist, metaphorical perception.

\section{GíRiş}

21. yüzyıl yeterlilikleri kapsamında bireylerin çağa ayak uydurabilmeleri için bilimsel okuryazar olmaları gerekmektedir (Belhan \& Şimşek, 2012; Bybee, 1997; Goodrum \& diğerleri, 2001). Eğitimde uzun yıllardır devam eden yeniden yapılanma çalışmalarının önemli hedeflerinden biri bilimsel okuryazar bireyler yetiştirmektir (American Association for the Advancement of Science [AAAS], 1989, 1990; National Research Council [NRC], 1996, 2004; National Science Education Standards [NCSS], 2010, 2019). Toplumdaki vatandaşları bilimsel okuryazar olarak yetiştirmek ve onları toplumsal hayata hazırlamak Milli eğitim amaçları içerisinde de yer alır (MEB, 2018). Bilimsel okuryazar bireyler yetiştirmek yeterli düzeyde bilimin doğası algısına, bilimsel araştırmanın bilgisine, bilimsel bilginin gelişimine yönelik öğretim ortamlarının yapılandırılması ile mümkün olacaktır (Abd-El-Khalick \& diğ., 1998; Lederman, 2006). Bilimin doğasının bir parçası olan "bilim insanının kim olduğu ve hangi rolleri üstlendiği”" algısı da önem kazanmaktadır. Özellikle, mesleki bilginin kazandırıldığı lisans eğitimi döneminde, öğretmen adaylarının almış oldukları eğitim bilimsel araştırma ve bilim insanı algıları açısından öne çıkmaktadır. Öğrencilerin bilim ve bilim insanına yönelik gerçekçi ve olumlu bir imaja sahip olmaları, onlara doğru bilgiler verebilecek ve bilim insanı imajlarını gerçekçi bir temele oturtabilecek öğretmenlerin katkısıyla sağlanabilir. Bireyin bilim insanına yönelik imajları olumsuz öğelere sahip ise, bu bireyin bilim ve bilim ile ilgili etkinliklere karşı olumlu tutum geliştirmesine engel olacaktır. Bu konu araştırmacıların uzun yıllar ilgisini çekmiştir. Ülkemizde özellikle öğretmen adaylarının bilim insanı imaj ve algılarına yönelik araştırmalar vardır (Ağgül Yalçın, 2012; Çermik, 2013; Demirbaş, 2009; Ürey \& diğ., 2017).

Öğretmen adaylarının bilimsel araştırma ve bilim insanlarına yönelik metaforik algılarını tespit etmek amacıyla yapılan araştırmalar incelenmiştir (Bartan, 2019; Çetin \& diğ., 2019; Harman \& Şeker, 2019; Kösem, 2017; Özgün \& diğ., 2018; Taşdemir \& Taşdemir, 2016). Fen bilgisi öğretmen adaylarıyla yapılan çalışmaların katılımcıların bilimsel araştıma ve bilim insanı algılarının yanında bilimsel yöntem, bilimsel bilgi, bilimin doğası kavramlarına yönelik algılarını tespit etmeye yönelik çalışmalar olduğu görülmüştür (Ağgül \& Yalçın, 2012; Harman \& Şeker, 2019; Özkan \& diğ., 2017). Sınıf öğretmeni adayları (Kösem, 2017), okul öncesi öğretmen adayları (Şenel \& Aslan, 2014; Taşdemir \& Taşdemir, 2016) ile yapılan çalışmaların ise bilimsel araştırma ve bilim insanı kavramına yönelik algılarını tespit etmeye yönelik çalı̧̧alar olduğu görülmektedir. Örneğin Harman ve Şeker (2019) fen bilgisi öğretmen adaylarının bilimsel araştırmaya yönelik metaforik algılarında bilimin doğası özelliklerine yer verirken, Kösem (2017) sınıf öğretmeni adaylarının ve Bartan (2019) okul öncesi öğretmen 
adaylarının bilimsel araştırma ve bilim insanı metaforik algılarında bilimin doğası özelliklerine değinmedikleri görülmektedir. Ayrıca farklı branşlardaki öğretmen adaylarının bilimsel araştırma ve bilim insanını kavramına yönelik geliştirdikleri meteforların karşılaştırılmasına yönelik araştırmalar da görülmektedir (Angın \& Ozanoğlu, 2019; Çetin \& diğ., 2019; Özgün \& diğ., 2018; Ürey \& diğ., 2017; Yalçın, 2012). Alan yazında okul öncesi öğrencilerinden, üniversite öğrencilerine kadar bilimsel araştırma ve bilim insanına yönelik metaforik algılarını tespit etmeye yönelik araştırmalar yer alır (Bıyıklı \& diğ., 2014; Kalayc1, 2018; Uslu \& diğ., 2016). Sosyal bilgiler öğretmen adaylarının bilimsel araştırmalara yönelik algılarını tespit etmeye yönelik az sayıda araştırmaya rastlanmıştır (Demirkaya \& Çal, 2018; Ürey \& diğ., 2017). Bu çalışmaların amaçları doğrudan sosyal bilgiler öğretmen adaylarının bilimsel araştırma ve bilim insanına yönelik algıların tespit edilmesi değil sosyal bilgiler öğretmen adaylarının bilim ve bilim insanına yönelik algılarını fen bilgisi öğretmenleriyle karşılaştırılması ya da bilimsellik değerine yönelik metaforik algılarının tespiti amacıyla yapılan araştırmalardır. Farklı alanlardaki öğretmen adaylarıyla yapılan araştırmalar da vardır. Örneğin Harman ve Şeker (2019) fen bilgisi öğretmen adaylarının, Kösem (2017) sınıf öğretmeni adaylarının, Bartan (2019) okul öncesi öğretmen adaylarının bilimsel araştırma ve bilim insanı metaforik algılarını belirlemiş̧lerdir. Alan yazında okul öncesi öğrencilerinden, üniversite öğrencilerine kadar bilimsel araştırma ve bilim insanına yönelik metaforik algılarını tespit etmeye yönelik araştırmalar yer almaktadır (Bıyıklı \& diğ., 2014; Kalaycı, 2018; Uslu \& diğ., 2016). Alanyazındaki araştırmalar incelendiğinde katılımcıların özellikleri, seviyeleri, yaş grupları değişmesine rağmen bilimsel araştırma ve bilim insanına yönelik ortak metaforlar oluşturdukları tespit edilmiştir. Bunun yanında bilim insanına yönelik algıyı tespit etmek amacıyla Draw a Scientist Test (DAST) kullanan araştırmalar da vardır (Angın \& Ozanoğlu, 2019; Bilir \& diğ., 2020; Çermik, 2013; Ürey \& diğ., 2017; Özkan \& diğ., 2017; Sezen Vekli \& diğ., 2020; Yalçın, 2012).

\section{Araştırmanın Amacı}

Sosyal bilgiler öğretmen adaylarının bilimsel araştırma ve bilim insanına yönelik metaforik algılarını tespit etmeyi amaçlayan çalışmada aşağıdaki sorular cevaplanmaya çalışılmıştır:

1. Sosyal bilgiler öğretmen adaylarının bilimsel araştırma kavramına yönelik sahip oldukları metaforlar nelerdir?

2. Sosyal bilgiler öğretmen adaylarının bilim insanı kavramına yönelik sahip oldukları metaforlar nelerdir?

3. Sosyal bilgiler öğretmen adaylarının sahip oldukları bilim insanı imajları nasıldır?

\section{YÖNTEM}

\section{Araştırmanın Deseni}

Araştırma sosyal bilgiler öğretmen adaylarının bilimsel araştırma ve bilim insanına yönelik metaforik algılarını belirlemek amacıyla nitel araştırma yaklaşımlarından olgu bilim araştırma deseni kullanılarak gerçekleştirilmiştir. Olgu bilim, farkında olunan ancak derinlemesine ve ayrıntılı bir şekilde anlayışa sahip olunmayan durumlara odaklanmaktadır. Olgu bilim araştırma deseni, bir olguyu daha iyi anlamamızı sağlayacak örnekler, araştırmalar ve yaşantılar sunarak hem bilimsel alanyazına hem de uygulamaya önemli katkılar getirebilir (Yıldırım ve Şimşek, 2011). 


\section{Katilimcilar}

Araştırma sosyal bilgiler öğretmenliği bölümünde öğrenim gören 1., 2., 3. ve 4.sınıf sosyal bilgiler öğretmen adayları (145 kişi) ile yapılmıştır. Araştırmaya katılan bireylerin seçiminde amaçlı örneklem yöntemlerinden hızlı ve pratik olması nedeniyle kolay ulaşılabilir örneklem yöntemi kullanılmıştır (Yıldırım ve Şimşek, 2011). Çalışmanın gerçekleştirilebilmesi için Zonguldak Bülent Ecevit Üniversitesi İnsan Araştırmaları Etik Kurulundan 21.04.2021 tarih ve 34726 sayılı izin alınmıştır. Katılımcılara ait bilgiler Tablo 1'de verilmiştir.

Tablo 1. Katılımcılara Ait Bilgiler

\begin{tabular}{llcc}
\hline Değişken & Tür & Frekans & Yüzde \\
\hline Cinsiyet & Kadın & 94 & 64.82 \\
& Erkek & 49 & 33.79 \\
& Bilinmiyor & 2 & 1.37 \\
\hline Soplam & 145 & 100 \\
\hline Toüzeyi & 1.sinıf & 41 & 28.27 \\
& 2. sinıf & 40 & 27.58 \\
& 3. sinıf & 25 & 17.24 \\
& 4. sinıf & 39 & 26.89 \\
& Toplam & 145 & 100 \\
\hline
\end{tabular}

\section{Veri Toplama Araçları}

Veri toplama aracı olarak birinci kısmında katılımcıların demografik değişkenleri belirlemeye yönelik sorulara, ikinci kısmında ise "Bilimsel araştırma... gibidir, çünkü ...." ve "Bilim insanı..... gibidir, çünkü ......" cümle kalıbına yer verilen yarı yapılandırılmış form (Akçay, 2016; Saban, 2004) ve Chambers (1983) tarafından geliştirilen 'Bir Bilim İnsanı Çiz Testi' kullanılmıştır.

\section{Verilerin Analizi}

Araştırma kapsamında elde edilen verilerin analizlerinde analizci tümevarım yaklaşımı benimsenmiş, veriler içerik analizi tekniğiyle analiz edilmiştir. Analizci tümevarım, kavram ve fikirleri geliştirmede olaylar arası benzerliklerin sistemli şekilde incelenmesini sağlayan nitel araştırmalarda sıkça kullanılan bir yaklaşımdır (Balcı, 2015; Ragin, 1994). İçerik analizi ise kalıpları, temaları, önyargıları ve anlamları tespit etmek amacıyla belli bir materyalin ayrıntılı şekilde incelenmesi ve yorumlanmasıdır (Berg ve Latin, 2008; Berg ve Lune, 2015; Yıldırım ve Şimşek, 2011). İçerik analizi tercih edilmesinin sebebi araştırma verilerini kodlar, temalar, kategoriler ve veri örnekleri halinde organize ederek sınıflandırmaktır (Labuschagne, 2003).

Nitel araştırmalarda verilerin daha kolay anlaşılması ve değişik temalar ve örüntüler oluşturabilmek için verilerin özetlenmesi ve azaltılması gerekmektedir (Berg ve Lune, 2015). İlk olarak öğretmen adayları tarafından üretilen metaforların alfabetik olarak bir listesi oluşturulmuştur. Bu listeye göre toplanan veriler belli bir metaforu tanımlayıp tanımlamadığına bakılmıştır. Herhangi bir metaforu tanımlamayan, metafor yerine kendi görüşünü bildiren ya da "çünkü....." ifadesi, olmayan dokümanlar ayrılarak analiz dışı tutulmuştur. Verilerin hangi öğretmen adayına ait olduğunu ifade etmek için ' $1 \mathrm{~K} 23$ ', birinci ifade sınıf seviyesini, ikinci ifade cinsiyet durumunu, üçüncü ifade form sırasını belirtecek şekilde rumuz verilmiştir.

Araştırmacılar üretilen metaforları ortak özelliklerine göre aralarındaki ilişkileri dikkate alarak birbiriyle ilișkili kodlar, kodları bir araya getirilerek kategoriler, kategorilerden de temalar oluşturmuşlardır (Patton, 2002). Oluşturdukları temalar arası ilişkiler incelenerek veriler arasında karşılaştırmalar yapılmıştır (Read \& diğ., 2016). Araştırmacılar tümevarımsal bir 
yaklaşım izleyerek kodlar arasındaki ilişkiyi, çakışan ya da kesişen kodları belirlemek amacıyla temaları sınıflandırmışlardır. Birbiriyle çelişen ya da kesişen kodların belirlenmesi kodlar arası mantıksal bir yapı oluşturmaktadır bu yapı nitel veri analizinde tutarlılığı sağlamaktadır (Shenton, 2004).

Veri analizi sonucu ulaşılan kategoriler, metaforlar, metaforların sayısı ve frekans değerleri tablo halinde sunulmuştur. Her kategori için metaforlara ait örnek ifadeler veya çizimler katılımcılardan doğrudan alıntılar yapılarak açıklanmıştır. Verilerin sunumunda, araştırma amacıyla ilgili alanyazında yer alan farklı sonuçlarla karşılaştırmalar yapılmıştır (Cresswell, 2003).

Nitel araştırmalarda veri analizin son aşaması araştırmanın doğruluğunu sağlamaktır (Berg ve Lune, 2015). Araştırmanın doğruluğunu sağlamak için farklı kodlayıcılar tarafından aynı veri setine ilişkin kodlama yapılması önemlidir (Patton, 2002). Araştırmanın veri analizi iki araştırmacı ile yapılmıştır. Araştırmacılar arası görüş ayrılığı olan durumlarda araştırmacılar birbirlerini ikna ederek uzlaşma sağlamışlardır (Gay \& diğ., 2006; Sönmez ve Alacapınar, 2011).

\section{BULGULAR}

Bu bölümde, öğretmen adaylarının "bilimsel araştırma" ve "bilim insanı" kavramlarına yönelik olarak geliştirdikleri metaforlar ve bu metaforların yer aldığ 1 kategoriler tablolar halinde verilmiştir.

\section{Bilimsel araştırmaya yönelik metaforlara ilişkin bulgular}

Öğretmen adaylarının "bilimsel araştırma" kavramına yönelik geliştirdikleri metaforlar yöntem, bilimin doğası ve kavram yanılgıları kategorilerinde toplam 119 metafor üretmişlerdir. Bilimsel araştırma kavramını açıklamak için kullanılan metaforların frekans dağılımları Tablo 1 'de verilmiş, her kategori için metaforlara ait örnek ifadelerden doğrudan alıntılar yapılarak açıklanmıştır. 
Tablo 2. Bilimsel Araştırmaya Yönelik Öğretmen Adaylarının Metaforik Algıları

\begin{tabular}{|c|c|c|c|c|}
\hline & Kategori & Metaforlar & $\begin{array}{c}\text { Metafor } \\
\text { sayis! }\end{array}$ & $\mathbf{f}$ \\
\hline \multirow[t]{2}{*}{ Yöntem } & Araştırmaya dayalı & $\begin{array}{l}\text { Ağaç, aklın becerilere dökülmesi, araba, ayakkabı bağı, } \\
\text { bazı şeylere çözüm aramak, beynin iç yapısı, bilgisayar, } \\
\text { bilgi yolculuğu, bina, bir bütünü oluşturan parça, bomba, } \\
\text { çıarım, çocuk büyütmek, deney yapmak, derine } \\
\text { inceleme, ders, düşüncenin ürünü, gelecek, gerçeğin } \\
\text { yansıması, güneş(2), 1şı, inci, keşfedilmemiş gezegen, } \\
\text { keşfedilmeye hazır kıta, matematik (2), merak (2), } \\
\text { merdiven, meyve, net bilgiye ulaşmak, netliği bulmak, } \\
\text { okul(2), puzzle, somut bilgiler, somut bir yolculuk, tatlı } \\
\text { ve ekşi, yeni doğmuş bir çocuk, yeni renkler keşfetmek, } \\
\text { yol (3) }\end{array}$ & 38 & 44 \\
\hline & Amaca yönelik & $\begin{array}{l}\text { Bilim 1şı̆ğ, bina, bir çiçek, bir gizem olayı, bir yeme } \\
\text { içme, bisiklet sürmeyi öğrenmek, değerlendirme formu, } \\
\text { doğa, doğru yola gitmek, dünya, fenerbahçe, gerçeği } \\
\text { aramak, güneş, hayat (2), ilaç (2), ince bir ip üzerinde } \\
\text { yürümek, insan beyni, insanların yaşamlarına yeni bilgi } \\
\text { üretmek, insanlık için 1şı, ip, kitap, kumar, merdiven, } \\
\text { nesnel yöntemleri kullanmak, olasıllk, olgunlaşma } \\
\text { yolundaki meyve, öğretmen, sanat, semavi dinler, toprak, } \\
\text { yeni bir şeyler keşfetme, yol (2), }\end{array}$ & 32 & 35 \\
\hline \multirow[t]{4}{*}{$\begin{array}{l}\text { Bilimin } \\
\text { doğası }\end{array}$} & Birikimli olması & $\begin{array}{l}\text { Ağaçtaki meyve, arkeoloji kazısı, basamak, boş bir } \\
\text { defteri doldurmak, evrendeki kayalar, hazineden çıkan } \\
\text { altın, merdiven, öğrenci, puzzle (2), tuğla örmek, } \\
\text { yolculuk, }\end{array}$ & 11 & 12 \\
\hline & Değiş̧ebilirlik & $\begin{array}{l}\text { Akan bir nehir, dinamik bilgi, eşya, gezegenler, ışı, } \\
\text { organlarımız, su (2), yaşam, }\end{array}$ & 8 & 9 \\
\hline & $\begin{array}{l}\text { Çok boyutluluk } \\
\text { (birikimli) }\end{array}$ & Hayat, nar, tablo, yaşantı, yemek & 5 & 5 \\
\hline & Sinırsizlık & $\begin{array}{l}\text { Akan bir nehir, deniz (2), doğadaki renkler, doğrusal } \\
\text { çizgi, dünya, evren (6), gelecek (2), gökyüzü (2), okyanus } \\
\text { (4), su, toprak, yaşam, yol (2), }\end{array}$ & 13 & 25 \\
\hline \multirow[t]{3}{*}{$\begin{array}{l}\text { Kavram } \\
\text { yanılgıları }\end{array}$} & $\begin{array}{l}\text { Teknolojiyle } \\
\text { karıştırma }\end{array}$ & $\begin{array}{l}\text { Akıllı tahta, felsefe alanı, sihirli güç, teknoloji, yeni bir } \\
\text { buluş, }\end{array}$ & 5 & 5 \\
\hline & Kesinlik & $\begin{array}{l}\text { Aklın mantıklı olan bölümü, bilgiye ulaşmak, dünyanın } \\
\text { geoit oluşu, insanlar için gerekli bir bilgi, objektif } \\
\text { çalışma, terazi }\end{array}$ & 6 & 6 \\
\hline & Bilimde Tek Yöntem & Deney & 1 & 1 \\
\hline Toplam & & & 119 & 142 \\
\hline
\end{tabular}

\section{Yöntem}

Yöntem kategorisinde araştırmaya dayalı ve amaca yönelik metaforik ifadeler yer almaktadır. Katılımcılar bilimsel çalışmaların araştırmaya dayalı olduğuna dair yol (3), güneş (2), matematik (2), merak (2), okul (2) en sık tekrarlanan ifadeler olmak üzere toplam 38 metafor üretmişlerdir. $\mathrm{Bu}$ kategorideki metaforların ortak özellikleri incelendiğinde bilimsel araştırmaların gerçeği/doğruyu bulmak amacıyla yapılan araştırmalar/çalışmalar olarak ifade ettikleri için bu kategori "araştırmaya dayalı" olarak isimlendirilmiştir. Bu kategorideki metaforlara örnek ifadeler aşağıda sunulmuştur.

"Bilimsel araştırma gerçeğin yansıması gibidir. Çünkü bir gerçek vardır ve bu gerçek doğru araştırllarak bulunur.” (1K21) 
"Bilimsel araştırma net bilgiye ulaşmak gibidir. Çünkü sistemli veri toplama ve analiz etme işidir. Yeni bir teori-kuram geliştirmek veya sinamak için de yapılır.” (2E55)

"Bilimsel araştırma meyve gibidir. Çünkü bilimsel araştırmada meyve gibi emek ister. Meyve de bilimsel araştırma da emek olmadan yarar sağlamaz.” (2K59)

"Bilimsel araştırma okul gibidir. Çünkü bir aşamadan başlar ve sonuca ulaşana kadar birbirini takip eden halkalardan oluşur.” (2K61)

"Bilimsel araştırma puzzle gibidir. Çünkü bir puzzleda ilk önce parçaları tek tek arayıp onları bulup birleştirmek gerekiyor. Bilimsel araştırmada da verileri tek tek bulup onları birleştirip bir sonuca varır." (2K78)

Bilimsel araştırmaların yöntemine ilişkin diğer bir kategori bilimsel araştırmaların amacına yönelik ifadelerin yer aldığı kategoridir. Katılımcılar bilimsel araştırmaların amacına yönelik hayat (2), ilaç (2), yol (2) en sık tekrarlanan ifadeler olmak üzere toplam 32 metafor üretmişlerdir. $\mathrm{Bu}$ kategorideki metaforların ortak özellikleri incelendiğinde bilimsel araştırmaların amacının bilinmeyeni ortaya çıkarma, araştırma yapma, bilgi edinme olarak ifade ettikleri için bu kategori "amaca yönelik" olarak isimlendirilmiştir. Bu kategorideki metaforlara örnek ifadeler aşağıda sunulmuştur.

"Bilimsel araştırma bir gizem olayı gibidir. Çünkü bilinmeyen ve henüz açıklanmamış bir olayı ortaya çıkararak insanlığa açıklamak bilim insanının borcudur.” (1K13)

"Bilimsel araştırma merdiven gibidir. Çünkü adım adım ilerlenir, tüm bulgular, araştırmalar, incelemeler ve sonuçlardan oluşur. Adım adım son basamağa kadar gidersin.” (1K27)

"Bilimsel araştırma ilaç gibidir. Çünkü normal bir hastanın tedavisinde kullanmak için ilaç nasıl gerekliyse yaşamı ilerletmek için de bilimsel araştırma gereklidir. Ama ilacı ihtiyaç varken kullandığımızda fayda edip farklı amaçlarda kullanıldı̆̆ında nasıl zarar veriyorsa bilimsel araştırmada yaşama katkı için kullanıldığında iyilik, yaşam almak için kullanıldı̆̆ında kötülüğe dönüşür." (1K33)

“Bilimsel araştırma bisiklet sürmeyi ögrenmek gibidir. Çünkü öğrenmek için çabalarken ĕger vazgeçmezsek ögrendiğimizde daha uzak yollara açılmak isteriz. Bilimsel araştırmada da ortaya koyduğumuz veriler bizlerin isteğini artırır." (4E132)

\section{Bilimin Doğasına Yönelik Ifadeler}

Bilimin doğası kategorisinde bilimin değişebilir doğası, birikimli olması, sınırsızlı̆̆ boyutlu oluşuna yönelik metaforik ifadeler yer alır. Katılımcılar bilimin değişebilirliğine yönelik akan bir nehir, dinamik bilgi, eşya, gezegenler, 1şık, organlarımız, su (2), yaşam gibi ifadeler kullanmışlardır. Bu kategorideki metaforlara örnek ifadeler aşağıda sunulmuştur.

"Bilimsel araştırma yaşam gibidir. Çünkü her zaman yenilenir, yeni şeyler katar ve yeni şeyler ögretir.” (1K30)

“Bilimsel araştırma gezegenler gibidir. Çünkü sürekli kendini yeniler.” (1E6) 
"Bilimsel araştırma su gibidir. Çünkü sürekli kendini yeniler. Her gözlemden deneyden sonra farklı bir sonuç ortaya çıkabilir. Farklı sonuçlar elde edilir. Bu şekilde sürekli kendini yeniler.” (2E43)

"Bilimsel araştırma dinamik bilgiler gibidir. Çünkü bilimsel araştırmalar sürekli aynı değildir. Zaman içinde değişime uğrar.” (3K87)

"Bilimsel araştırma eşya gibidir. Çünkü bir bilimsel araştırma var olan eki bir araştırmayı çürütebilir, o bilgiyi tarihe gömebilir." (3K92)

Katılımcılar bilimin birikimli olmasına yönelik ağaçtaki meyve, arkeoloji kazısı, basamak, boş bir defteri doldurmak, evrendeki kayalar, hazineden çıkan altın, merdiven, öğrenci, puzzle (2), tuğla örmek, yolculuk ifadelerini kullanmışlardır. Bu kategorideki metaforlara örnek ifadeler aşağıda sunulmuştur.

"Bilimsel araştırma arkeoloji kazısı gibidir. Çünkü yeri kazdıkça değişik bulgular çıkar ve daha derine doğru inilir." (1K14)

"Bilimsel araştırma puzzle gibidir. Çünkü bilimsel araştırmada puzzleda olduğu gibi adım adım ilerlenir. Her bir parçayı birleştirdiğimizde bütüne yaklaşırız.” (2K63)

Katılımcılar bilimin çok boyutlu olmasına yönelik olarak hayat, nar, tablo, yaşantı, yemek ifadelerini kullanmışlardır. Bu kategorideki metaforlara örnek ifadeler aşağıda sunulmuştur.

"Bilimsel araştırma tablo gibidir. Çünkü her tez sentez bütünlük içinde sanki bir kompozisyonun parçası gibidir.” (3K82)

"Bilimsel araştırma nar gibidir. Çünkü dışarıdan bir bütün gibi görünse de içini açtığımızda çoğalır, dallara ayrılır.” (4E134)

\section{Kavram Yanılgilart}

Öğretmen adaylarının bilimsel araştırmaya yönelik bazı kavram yanılgılarına sahip oldukları tespit edilmiştir. Bu yanılgılar bilimi teknolojiyle karıștırma, bilimin kesin olduğu yanılgısı ve bilimde tek yöntem yanılgısı olarak belirlenmiştir. Katılımcılar bilimi akıllı tahta, felsefe alanı, sihirli güç, teknoloji, yeni bir buluş olarak ifadelerini kullanmaları bilimin teknolojiyle karıştırılmasına yönelik yanılgılar olarak tespit edilmiştir. Bu kategorideki metaforlara örnek ifadeler aşağıda sunulmuştur.

"Bilimsel araştırma teknoloji gibidir. Çünkü bilim insanları insanların hayatlarını kolaylaştırmak için çalışmalar yapar." (1K32)

"Bilimsel araştırma akıllı tahta gibidir. Çünkü akıllı tahtayı çözmek programları kullanmak zordur ama etkili kullanıldığında çok faydalıdır." (1K20)

Katılımcılar bilimsel araştırmaya yönelik aklın mantıklı olan bölümü, bilgiye ulaşmak, dünyanın geoit oluşu, insanlar için gerekli bir bilgi, objektif çalışma, terazi olarak ifade etmeleri bilimin kesinlik içerdiği yönündeki ifadeler olarak tespit edilmiştir. Bu kategorideki metaforlara örnek ifadeler aşağıda sunulmuştur. 
"Bilimsel araştırma objektif çalışma gibidir. Çünkü öznellik söz konusu değildir ortaya çıkan teoriler nesnel ve objektiftir." (2K72)

"Bilimsel araştırma aklın mantıklı olan bölümü gibidir. Çünkü gerçektir, somuttur, doğruluğu kabul edilebilir, değiştirilemez ve evrenseldir." (4K115)

Katılımcıların bilimde tek yöntem yanılgısına yönelik bilimi deney olarak gördükleri ifadelerdir. Bu kategorideki metaforlara örnek ifadeler aşağıda sunulmuştur.

"Bilimsel araştırma bilgiye ulaşmak gibidir. Çünkü yapılan araştırmalarda deneyler mutlak bilgiye ulaşmak için tek araçtır.” (2E50)

Bilim insanına yönelik metaforlara ilişkin bulgular:Öğretmen adayları "bilim insanı" kavramına yönelik kişisel özellikler, mesleki özellikler, çalışma ortamı ve kullandığı araçlar kategorilerinde toplam 108 metafor üretmişlerdir. Bilim insanı kavramını açıklamak için kullanılan metaforların frekans ve yüzde dağılımları Tablo 3'de verilmiş, her kategori için metaforlara ait örnek ifadelerden doğrudan alıntılar yapılarak açıklanmıştır.

Tablo 3. Bilim İnsanına Yönelik Metaforik Algılar

\begin{tabular}{|c|c|c|c|}
\hline Kategori & Metaforlar & $\begin{array}{l}\text { Metafor } \\
\text { sayısı }\end{array}$ & $\mathbf{f}$ \\
\hline Kişisel & $\begin{array}{l}\text { Anne, anne ve okul, araştırmacı dedektif, arı ve karınca, bilgi küpü, çınar, } \\
\text { çocuk (4), değişik tipler, maceracı, mum, pratik zeki düşünen bir insan, } \\
\text { sabırlı, usta, üstün zekâlı varlıklar, yeni bir gün, zehir }\end{array}$ & 16 & 19 \\
\hline Mesleki & $\begin{array}{l}\text { Adalet, ağaç (8), altın, anahtar (2), anne (2), anne-baba, akarsu, araba, } \\
\text { araştırmacı-incelemeci, arı, aşçı, ateş, avcı, ayna, bahçıan(2), beyin, ,bilgi } \\
\text { kutusu ,bilgi makinası, bilim, bilimsel veri elde etmeye çalışan bilgi küpü, } \\
\text { bir toplumun kilit vatandaşları, bir yol gösteren, buluş, bulut, bu yaşamın } \\
\text { içindeki olaylar, coğrafi keşifler, çiftçi, dahi-üstün, dahiliğin üstü, dedektif } \\
\text { (3), deney aşaması, deneydeki en önemli malzeme, doğa, doğadaki mevsim, } \\
\text { doktor (2), dünyanın kurtarıcı, düşüncelerini gerçekleştiren insan, elektrikli } \\
\text { süpürge, elmas, evren, felsefeci, fener, firınc1, gece lambası, geleceğimize } \\
\text { yön veren, gezegen, güneş(5), hayalperest bir insan, hava-su, 1şık (3), ileti, } \\
\text { insan, insanlığa faydalı süpermen, insanlığın beyni, insanlığın yol } \\
\text { göstericisi, inşaatçı, işçi, kahraman, kalem, kaşif (2), kayıp bir gezgin, } \\
\text { keşfedilmemiş mücevher, kitap(3), limon, meyve veren ağaç, oksijen, } \\
\text { öğretmen(7), paradoks, problem çözücü makine, pusula, realist, rehber, } \\
\text { ressam, robot, saat, sanatçı (2), sonuca giden yolun anahtarı, } \\
\text { sorumluluklarını bilen asker, su (2), süper kahraman, sürekli keşif yapan } \\
\text { kaptan, toplumun aynası, yapboz, yaratıcı insan, yatırımcı, yazar, yemeği } \\
\text { yiyen kişi, }\end{array}$ & 87 & 117 \\
\hline $\begin{array}{l}\text { Çalışma } \\
\text { ortamı }\end{array}$ & Evren (her yer), dünya & 2 & 2 \\
\hline $\begin{array}{l}\text { Model Bilim } \\
\text { İnsanı }\end{array}$ & Aziz Sancar, Einstein, Hz. İsa & 3 & 3 \\
\hline Toplam & & 108 & 141 \\
\hline
\end{tabular}

\section{Kişisel Özellikler}

Bilim insanının sahip olduğu kişisel özelliklere yönelik anne, dedektif, arı, karınca, çocuk (4), değişik tipler, maceracı, mum, sabırlı, usta, üstün zekalı varlıklar, yeni bir gün, zehir gibi ifadeler olmak üzere toplam 16 metafor üretmişlerdir. Bu kategorideki metaforların ortak özellikleri incelendiğinde bilim insanlarının, çalışkan, araştırmacı zeki, meraklı bireyler olarak nitelendirilmektedirler. Bu kategorideki metaforlara örnek ifadeler aşağıda sunulmuştur. 
"Bilim insanı çocuk gibidir. Çünkü her şeyi merak etmekle birlikte bu merakını gidermek için çalışmalar yapmaktadır.” (2E50)

"Bilim insanı araştırmacı dedektif gibidir. Çünkü diğer insanların ilgisini çekmeyen belki de yapmaktan korktuğu işler peşine düşerler. Bu yüzden bilim insanları asla pes etmeyen kararlı araştırmacılardır." (2K66)

\section{“Bilim insanı zehir gibidir çünkü akıllı kurnaz zeki olmak zorundadır.” (4K111)}

Öğretmen adaylarının bilim insanı çizimleri incelendiğinde bilim insanı kişisel özelliklerinin bireysel çalışan ( $f=130)$, çalışkan ( $f=10)$, bilgili $(f=6)$, düzenli $(f=6)$, örnek kişiler $(f=6)$, ekiple çalışan $(\mathrm{f}=8)$, dağınık-deli dolu $(\mathrm{f}=4)$ olarak tasvir etmişlerdir. Bu tanımlara uygun olarak öğrencilerin bilim insanı çizimlerinden örnekler aşağıda sunulmuştur.

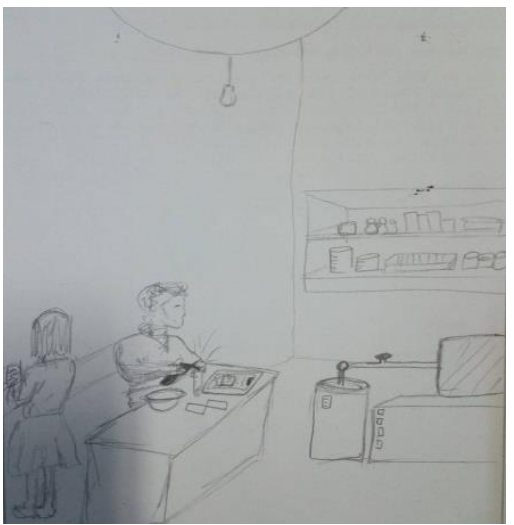

2K56 kodlu öğrenci çizimi

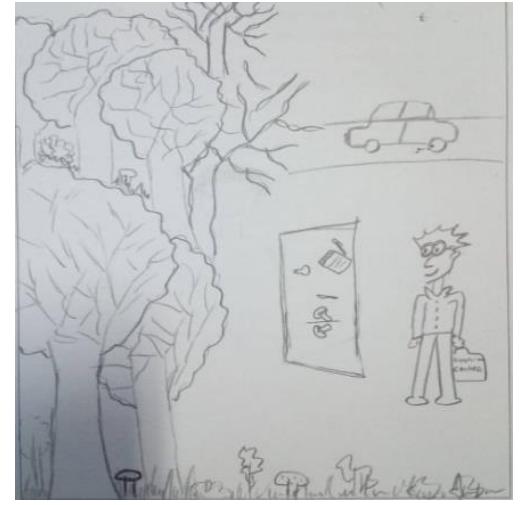

2K65 kodlu öğrenci çizimi

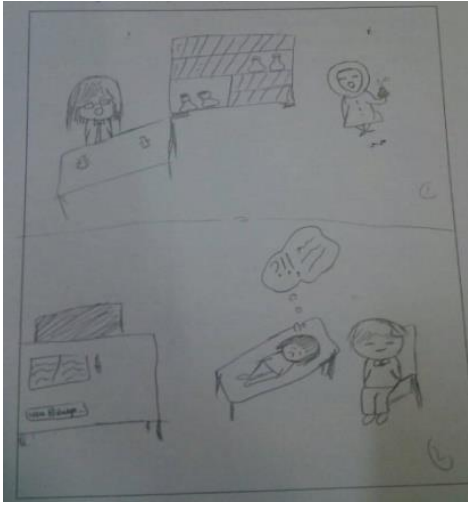

3K99 kodlu öğrenci çizimi

\section{Mesleki Özellikler}

Katılımcılar bilim insanının sahip olduğu mesleki özelliklere yönelik ağaç (8), anahtar (2), anne (2), dedektif (3), doktor (2), güneş (5), 1şık (3), kaşif (2), kitap (3), öğretmen (7), sanatç1 (2), su (2) en sik tekrarlanan ifadeler olmak üzere toplam 87 metafor üretmişlerdir. $\mathrm{Bu}$ kategorideki metaforlara örnek ifadeler aşağıda sunulmuştur.

"Bilim insanı firıncı gibidir. Çünkü firıncı simit elde etmek için hamuru yoğurup şekilden şekle sokar. Bilim insanı da doğru sonucu bulmak için bilimsel terimleri uygulayarak ortaya bilinmeyeni yani keşfedilmeyeni koyar." (1E4)

"Bilim insanı güneş gibidir. Çünkü sadece varlı̆̆ ile toplumu aydınlatmaya yeter. Hiçbir eylemde bulunmasa bir idol olmaya yeter." (1E9)

"Bilim insanı elektrikli süpürge gibidir. Çünkü etrafindaki olayları inceler, kavramları inceler, literatür tarama yapar, bilgi toplar ve bunlarl sentezler." (2E48)

Öğretmen adaylarının bilim insanı çizimleri incelendiğinde bilim insanı mesleki özelliklerinin deney yapan $(f=61)$, sorgulayan $(f=55)$, problem çözen $(f=10)$, çok yönlü düşünen $(f=13)$, icat yapan $(\mathrm{f}=17)$, meraklı $(\mathrm{f}=9)$ olarak tasvir edilmiştir. Bu tanımlara uygun olarak öğrencilerin bilim insanı çizimlerinden örnekler aşağıda sunulmuştur. 


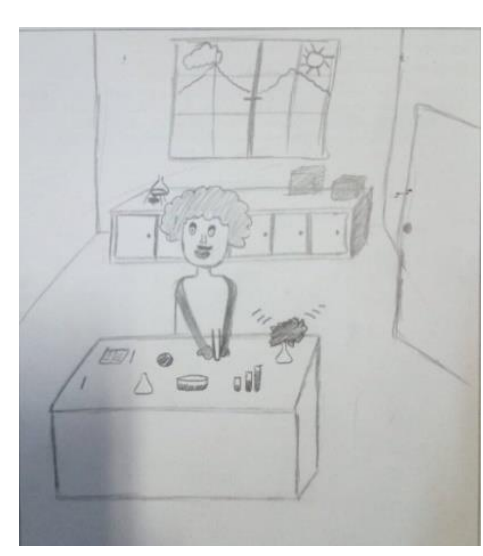

2K75kodlu Öğrenci Çizimi

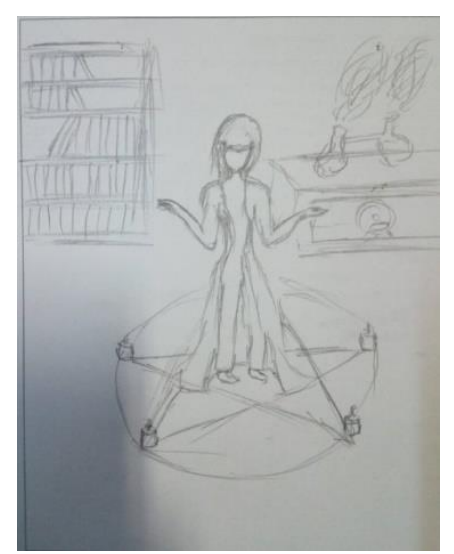

1E7 Kodlu Öğrenci Çizimi

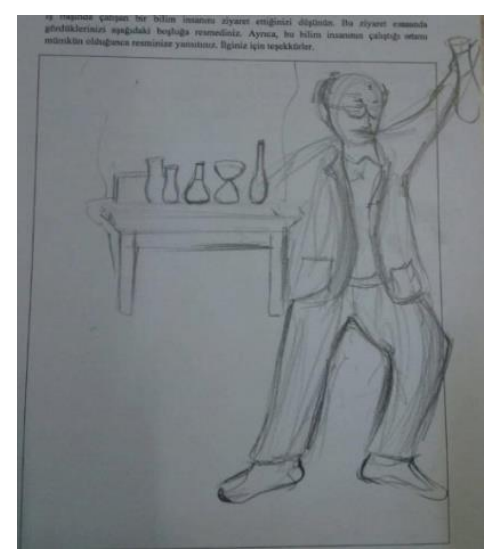

3K82 Kodlu Öğrenci Çizimi

\section{Çalışma Ortamı ve Model Bilim İnsanı}

Bilim insanına yönelik diğer kategoriler çalışma ortamı ve model bilim insanı kategorileridir. Katılımcılar bilim insanının çalışma ortamını evren ve dünya, model bilim insanlarını ise Aziz Sancar, Einstein, Hz. İsa metaforları ile nitelemişlerdir. Bu kategorideki metaforlara örnek ifadeler aşağıda sunulmuştur.

"Bilim insanı bilimle kafayı bozmuş insan gibidir çünkü hayatının her köşesinde her anında bilim vardır sürekli bilimle ilgilenir." (4K124)

"Bilim insanı Einstein gibidir. Çünkü araştırma deney yapar ve bilgi doludur." (1K12)

"Bilim insanı Aziz Sancar gibidir çünkü mütevazi, çalışkan geldiği toplumu unutmayan yaşadlğı toplumun kültürel mirasin yansıtan, çallşkan bir birey olduğu için Aziz Sancar." (4E128)

"Bilim insanı $\mathrm{Hz}$ İsa gibidir çünkü insanlara gerçeği anlatmayı çalıştıkça dışlanır değeri ölünce anlaşılır." (4E137)

Öğretmen adaylarının bilim insanı çizimleri incelendiğinde bilim insanının çalı̧̧ma ortamı çoğunlukla laboratuvar ( $(\mathrm{f}=73)$, doğa $(\mathrm{f}=13)$, ofis $(\mathrm{f}=9)$, kütüphane $(\mathrm{f}=8)$, ev $(\mathrm{f}=11)$ gibi mekânlar tasvir edilmiştir. Bilim insanlarının kullandığı malzemeler laboratuvar malzemeleri $(\mathrm{f}=86)$, teknolojik malzemeler $(\mathrm{f}=43)$, doğal öğeler $(\mathrm{f}=20)$, kitaplar $(\mathrm{f}=58)$ olarak tasvir edilmiştir. Model bilim insanlarını ise Newton, Einstein, Canan Dağdeviren, Karl Marx, Edison, Darwin, Nikola Tesla, Aziz Sancar ve İlber Ortaylı olarak tasvir etmişlerdir. Bu tanımlara uygun olarak öğrencilerin bilim insanı çizimlerinden örnekler aşağıda sunulmuştur. 


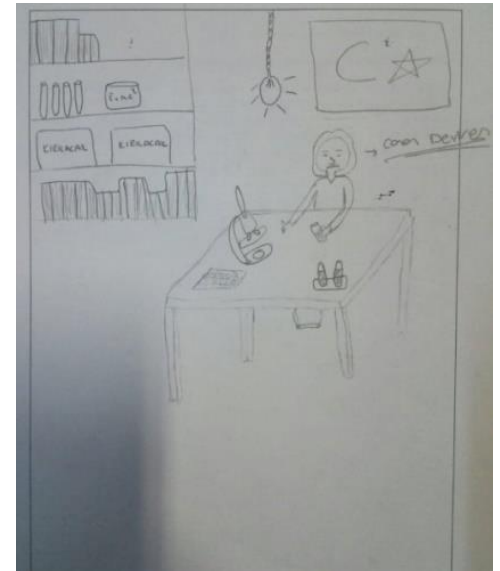

1K39 Kodlu Öğrenci Çizimi

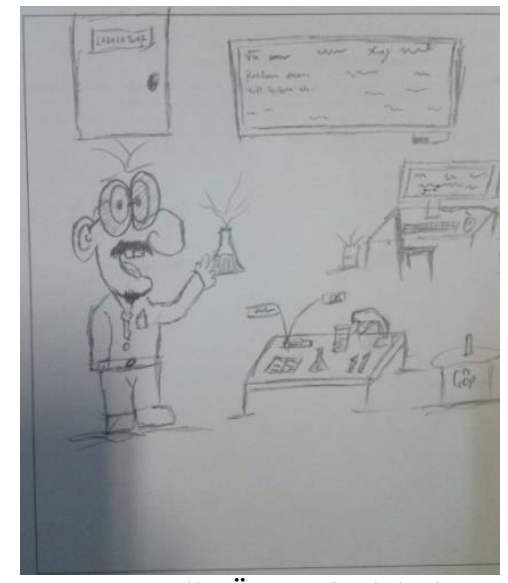

2E48 Kodlu Öğrenci Çizimi

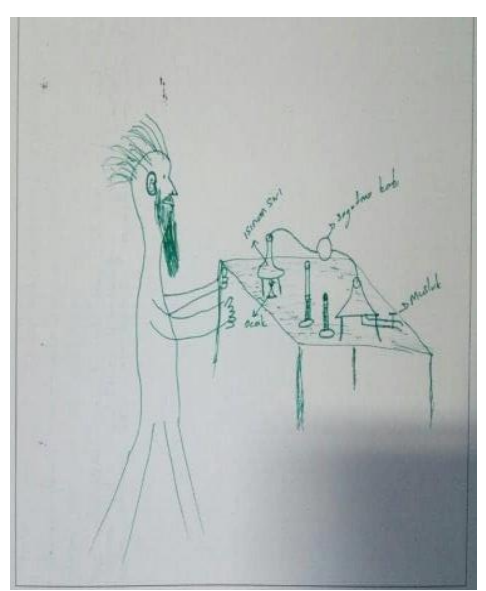

4E139 Kodlu Öğrenci Çizimi

\section{SONUÇLAR, TARTIȘMA VE ÖNERILER}

$\mathrm{Bu}$ çalışmada sosyal bilgiler öğretmen adaylarının bilimsel araştırma ve bilim insanı kavramlarına ilişkin algıları incelenmiştir. Araştırma sonucunda 145 sosyal bilgiler öğretmen adayının "bilimsel araştırma" kavramına yönelik yöntem, bilimin doğası ve yanılgılar kategorilerinde, "bilim insanı" kavramına yönelik kişisel özellikler, mesleki özellikler, çalışma ortamı ve kullandığı araçlar ve model bilim insanı olmak üzere 7 farklı kategori altına yerleştirilen 227 farklı metafor oluşturduğu saptanmıştır. Araştırma sonuçları öğretmen adaylarının bilimsel araştırmaya yönelik algıları ve bilim insanı kavramına yönelik algıları olarak sunulmuştur.

\section{Öğretmen Adaylarının Bilimsel Araştırmaya Yönelik Algıları}

Öğretmen adaylarının "bilimsel araştırma" kavramına yönelik yöntem, bilimin doğası ve yanılgılar kategorilerinde metaforlar üretmişlerdir. Yöntem kategorisinde araştırmaya dayalı ve amaca yönelik metaforik ifadeler yer alır. Öğretmen adayları bilimsel araştırmaları yönteme dayalı, doğruyu bulmak amacıyla yapılan çalışmalar olarak tanımlamışlardır. Alanyazındaki öğretmen adaylarıyla yapılan çalışmaların bilim ve bilimsel araştırma kavramları ile ilgili olumlu ve büyük oranda somut metaforlar ürettikleri görülmüştür (B1yılklı \& diğ., 2014; Derman \& Derman, 2015; Özgün \& diğ., 2018). Özgün ve diğ., (2018) öğretmen adaylar1 üzerinde yaptıkları araştırma sonuçlarına göre bilimsel araştırmanın "çaba-emek ve araştırmaya bağlı bir yapı", bilim insanını ise "araştıran-çabalayan-çalışkan bir kişi olarak algılandığını tespit etmişlerdir. Alan yazında farklı alanlardaki öğretmen adaylarıyla yapılan araştırmaların sonuçlarına göre öğretmen adaylarının bilimsel araştırmayı sonuca ulaşma şekli ve sonuca ulaşma sürecindeki işlemler olarak algıladıkları tespit edilmiştir (Akgün, 2012; Harman \& Şeker, 2019; Küçükoğlu \& diğ., 2013; Taşdemir \& Taşdemir, 2016). Taşdemir ve Taşdemir (2016) rehberlik ve psikolojik danışmanlığı öğretmen adayları üzerinde yaptıkları araştırma sonucunda bilimsel araştırma sürecini planlı, sistemli, aşamalı ve hazırlık isteyen bir süreç olarak algılandığını ortaya koymuşlardır. Benzer şekilde Harman ve Şeker (2019)'in araştırma sonuçları fen bilgisi öğretmen adayları bilimsel araştırmayı yeni bilgiler edinmek amacıyla planlı ve programlı sonuca ulaşma çabası olarak algılamaktadırlar. Bilimin araştırmaya dayalı olduğu ve bir yöntem dâhilinde yapılan çalışmalar olduğunu vurgulayan bu ifadeler araştırmanın sonucuyla da benzerlik göstermektedir. Öğretmen adayları bilimsel araştırmaları doğruyu bulmak, gerçeği öğrenmek ve bilgi edinmek amacıyla yapılan çalışmalar olarak ifade etmişlerdir. Alan yazındaki araştırma sonuçları benzer şekilde öğretmen adaylarının bilimsel 
araştırmaların amacının doğruyu bulmak, keşfetmek, bilgi edinmek olarak algıladıklarını tespit etmişlerdir (Akgün, 2012; Çepni \& diğ., 2003; Harman \& Şeker, 2019; Saban, 2007).

Bilimin doğası kategorisinde bilimin değişebilir doğası, birikimli olması, sınırsızlığı, çok boyutlu oluşuna yönelik metaforik ifadeler yer alır. Alanyazındaki bilimin değişebilir doğası ile ilgili farklı örneklem gruplarıyla yapılan araştırmalar vardır (Aktamış \& Dönmez, 2016; Bıy1klı \& diğ., 2014; Kösem, 2017; Özgün \& diğ., 2018; Şenel \& Aslan, 2014). Kösem (2017) sınıf öğretmeni adaylarının bilim algılarının yenilik, süreklilik içeren, gelişmeye açık olarak ifade etmiştir. Alanyazındaki farklı alanlardaki öğretmen adaylarının bilimsel bilginin değişebilir yapısına yönelik algılarını ortaya koyan araştırma sonuçları araştırmanın bu bulgusunu desteklemektedir (Akerson \& Abd-El-Khalick, 2005; Çakıc1, 2009; Çavuş, 2010; Çınar \& Köksal, 2013; Köksal \& Şahin, 2014; Saraç \& Cappellaro, 2015; Yenice \& di ğ., 2015).

$\mathrm{Bu}$ çalışmada öğretmen adaylarının çoğunun bilimsel araştırma kavramına yönelik var olan algılarının doğru olduğu tespit edilmiştir. Ancak öğretmen adaylarının bilimsel araştırmaya yönelik bazı kavram yanılgılarına sahip oldukları tespit edilmiştir. Bu yanılgılar bilimi teknolojiyle karıştırma, bilimin kesin olduğu yanılgısı ve bilimde tek yöntem yanılgısı olarak belirlenmiştir. Bazı öğretmen adayları bilimsel araştırmaları buluş, icat, yeni aletler üretme olarak algılamaktadır. Alan yazında bilim ve teknolojiyi birbiriyle ilișkili olarak ifade eden öğretmen adaylarıyla yapılan çalışmalar vardır (Aydın \& Taşar, 2010; Köksal \& Çınar, 2012; Zorlu \& Baykara, 2015). Bilim ve teknoloji aynı değildir fakat birbirini tamamlayan, gelişimlerine destek olan etkileşimli iki önemli alandır (Ryan \& Aikenhead, 1992). Araştırmanın bulguları arasında bazı öğretmen adaylarının bilimsel çalışmaların sadece deney ile gerçekleştiğine yönelik algıları bilimde tek yöntem yanılgısı olarak tespit edilmiştir. Alan yazında bilimsel yöntem konusunda kavram yanılgılarına sahip öğretmen adaylarının bulunduğuna yönelik araştırmalar vardır (Abd-El-Khalick \& BouJaoude, 1997; Chen, 2001; Çakıc1, 2009; Çavuş, 2010; Doğan, 2015; Dogan \& Abd-El-Khalick, 2008; Köseoğlu \& diğ., 2010; Tairab, 2001; Yakmacı, 1998). Akerson ve diğ., (2000) bilimde tek yöntemin olmadığını, bilimsel araştırmaların birden fazla yöntem aracılığıyla yapılabileceğini vurgulamıştır. Diğer bir kavram yanılgısı ise bilimin değişmez, kesin olduğuna yöneliktir. Bu sonuç, alanyazındaki bilimsel bilginin kesin olduğuna yönelik sonuçlarla benzerlik göstermektedir (Ayvac1 \& Er Nas, 2010; Çavuş, 2010; Dikmenli, 2010; Kösem, 2017). Benzer şekilde Kösem (2017)'in araştırma sonucu öğretmen adaylarının bilimsel bilgilerin değişmez ve kesin sonuçlar verdiği yönündedir. Öğretmen adaylarının bilim tanımları doğa bilimlerinin şekillendirdiği pozitivist anlayışa uygun tanımlardır. Bazı katılımcılara göre bilim değişmez niteliğe sahip, yalın, deney ve gözlem yoluyla tekrarlanabilen çalışmalardır. Benzer bulgular katılımcıların bilim insanlarına yönelik algılarında da görülmektedir. Katılımcıların bir kısmı bilim insanını deney ve gözlem yöntemlerini kullananan, labarotuvarda çalışan kişiler olarak algılamaktadır. Boyraz \& Kılıçer (2017) tarafından yapılan çalışmada İktisadi ve İdari Bilimler Fakültesi öğrencilerinin bilim algılarının pozitivist olduğu görülmüştür. Bu sonuç daha önce yapılan çalışma sonuçlarıyla da uyumludur (Çeliker-Deniş \& Avcı-Erduran, 2015; Gürgil, 2018; Terzi, 2005; Türk-Eyceyurt \& Tüzün, 2017). Pozitivizm, insan davranışlarının ve toplumsal olayların doğa bilimlerinin yasaları ile açıklama çabasıdır. Ancak insan ve onun etkileşimleri doğa bilimlerinin yöntemleriyle açıklanmayacak kadar karmaşıktır. Bu nedenle positivist anlayış sosyal bilimlerin yapısına uygun görülmemektedir. Terzi (2005)'ye göre öğrencilerin bilgi/bilim ile kurdukları ilişkide kitapların önemli bir etkisinin olduğu belirtilmektedir. Ders kitaplarındaki kavramlar, teoriler ve bilim insanı özellikleri positivist anlayışa göre hazırlanmıştır. Topçu ve Karatekin (2017) farklı yayınevleri tarafından yayınlanan 4., 5., 6. ve 7. sınıf sosyal bilgiler dersinde bilim adamlarına nasıl ve ne kadar yer verildiğini incemiştir. 
Kitaplarda sunulan 116 bilim insanından sadece 20'sinin sosyal bilimci olduğu tespit edilmiştir. Aynı çalışmada sosyal bilgiler dersinde verilen bilim insanı örnekleri ve bilimsel ifadelerin positivist yaklaşıma uyumlu doğa bilimciler açısından sunulduğu belirlenmiştir. Bu bulgu aynı zamanda bu alanda çalışan sosyal bilimcilerin ve bilim insanlarının yetersizliğini de göstermektedir. $\mathrm{Bu}$ yetersizliğin toplumda sosyal bilimler alanında çalışmalar yapan bilim insanlarının tanınmasını engellediği söylenebilir. Bu durumu ortadan kaldırmak için farklı disiplinlere ait örnek ve kavramların ders kitaplarına konulması önerilebilir (Gürgil, 2018; Rubin, Bar ve Cohen, 2003). Sosyal bilgiler dersi kitaplarında doğa bilimlerinde çalışmalar yapan bilim insanlarına yer verildiği gibi, fen bilgisi dersi kitaplarında sosyal bilimler alanında çalışmalar yapan bilim insanlarına ve onların çalışmalarına yer verilmelidir. Böylece sosyal bilimler alanında gereken toplumsal farkındalık arttırılabilir.

\section{Öğretmen Adaylarının Bilim İnsanına Yönelik Algıları}

Öğretmen adaylarının "bilim insanı” kavramına yönelik algıları kişisel özellikleri, mesleki özellikleri, çalışma ortamı ve kullandığı araçlara yönelik algılar olarak tespit edilmiştir. Öğretmen adayları bilim insanının sahip olduğu kişisel özellikleri çalışkan, araştırmacı zeki, meraklı bireyler olarak nitelendirilmektedirler. Alanyazında benzer sonuçlara rastlanmaktadır (Akçay, 2011; Bodzin \& Gehringer, 2001). Araştırmada önemli bir bulgu olarak öğretmen adaylarının çoğu bilim insanını bireysel çalışan kişiler ( $\mathrm{f}=130)$ olarak algılamaktadır. Bu bulgu alanyazındaki diğer araştırma sonuçlarıyla benzerdir (Angın \& Özenoğlu, 2019; Camc1Erdoğan, 2013; Çermik, 2013; Doğan, 2015; Yontar, 2013). Angın ve Özenoğlu (2019) bu sonucun, önemli çalışmalar yapan bilim insanlarının genellikle tek isimle anılmalarından kaynaklı olabileceğini savunmuştur.

Öğretmen adayları bilim insanının sahip olduğu mesleki özellikleri deney yapan, sorgulayan, problem çözen, topluma yol gösteren bireyler olarak algılamaktadırlar. Alan yazındaki araştırmaların sonuçları da bilim insanının laboratuvarda deney yapan kişiler olarak ifade edildiği görülmektedir (Camc1-Erdoğan, 2013; Finson, 2002; Kara, 2013; Kara \& Akarsu, 2015; Kaya \& di ğ., 2008; Kemaneci, 2012; Keser, 2012; Türkmen, 2008; Sezen Vekli \& diğ., 2020; Yalçın, 2012). Öğretmen adayları bilim insanının çalışma ortamının laboratuvar (f=73), doğa, ofis, kütüphane, ev gibi mekânlar olarak algılamaktadırlar. Alanyazındaki araştırma sonuçları incelendiğinde bilim insanlarının çalışma ortamları çoğunlukla laboratuvar olarak algılanmaktadır (Camc1-Erdoğan, 2013; Doğan, 2015; Kaya \& diğ., 2008; Kara, 2013; Kibar Kavak, 2008; Korkmaz \& Kavak, 2010; Ruiz-Mallen \& Escalas, 2012; Türkmen, 2008; Ürey \& diğ., 2017; Yontar, 2013). Ancak öğretmen adaylarına göre bilim insanlarının çalışma ortamını kütüphane, ofis ortamında çalışan kişiler olarak betimleyen araştırmaların olduğu görülür (Ürey \& diğ., 2017). Öğretmen adayları bilim insanlarının kullandığı malzemeler çoğunlukla laboratuvar malzemeleri olarak tasvir etmişlerdir. Alanyazında bu sonucu destekleyen benzer araştırma sonuçları vardır (Bilir \& diğ., 2020; Camc1-Erdoğan, 2013; Doğan, 2015; Kara, 2013; Kara \& Akarsu, 2015; Kibar Kavak, 2008; Korkmaz \& Kavak, 2010, Türkmen, 2008; Ürey \& diğ., 2017; Yalçın, 2012).

Araştırmanın önemli sonuçlarından biri de öğretmen adaylarının bilim insanlarına verdikleri örneklerde ortaya çıkmıştır Öğretmen adaylarının model olarak gördüğü bilim insanları; Canan Dağdeviren, Aziz Sancar, Newton, Einstein, Karl Marx, Edison, Darwin, Nikola Tesla, Aziz Sancar ve İlber Ortaylı' dır. Bu bulgu alanyazındaki araştırma sonuçlarıyla benzerdir (Ağgül Yalçın, 2012; Camc1-Erdoğan, 2013; Kara, 2013; Kibar-Kavak, 2008; Özkan \& di ğ., 2017; Özsoy \& Ahi, 2014). Öğretmen adaylarının bilim insanı örnekleri bilim, bilimsel araştırma ve bilim insanı özellikleri konusunda da önemli bilgiler sunmaktadır. Katılımcılar tarafından bilim 
insanlarına en çok verilen örnek Aziz Sancar, Newton, Einstein' dır (Boyraz \& Kılıçer, 2017; Demirbaş, 2009; Gürgil, 2018; Kıral, 2017). Aziz Sancar'ın 2015 yılında Nobel ödülünü alması öğretmen adayları tarafından en çok gösterilen bilim insanı olmasına neden olabilmektedir. Boyraz ve Kılıçer (2017) bilim insanlarının aldıkları ödüllerin tanınırlıklarını arttırdığını belirtmektedir. Öğretmen adayları tarafından örnek gösterilen diğer bir bilim insanı İlber Ortaylı'dır. İlber Ortaylı'nın medyada sık yer alması ve popüler olması öğretmen adayları tarafından örnek gösterilme nedeni olabilir. Araştımada bazı katılımcıların bilim insanınına yönelik kafalarının karışık olduğu tespit edilmiştir. Örneğin Hz. İsa bilim insanı olarak gösterilmiştir. Bu kafa karışıklığının nedeni öğretmen adaylarının bilim insanları hakkında yeterli bilgiye sahip olmadıklarını göstermektedir.

Araştırmanın bir diğer önemli bulgusu katılımcıların bilim insanı örneklerinden birinin Türk kadın bilim insanı Canan Dağdeviren olmasıdır. Bunun nedeni Canan Dağdeviren'in aldığı uluslararası ödül nedeniyle medyada çok sık yer almasından kaynaklanmaktadır. Medyada yer almak bilim insanının tanınırlığını arttırmaktadır. Öğretmen adayları Canan Dağdeviren örneği dışında kadın bilim insanına örnek vermemişlerdir. Alan yazındaki araştırmalar kadın bilim insanı algısı farklı yaş gruplarında da benzerdir (Akcay, 2011; Boyraz \& K1lıçer, 2017; Demirbaş, 2009; Gürgil, 2018; Karaçam \& diğ., 2014; Kıral, 2017; Küçük \& Bağc1, 2012; Losh \& diğ., 2008; Medina-Jerez \& diğ., 2011; Samaras \& di ̌̆., 2012; Toğrol, 2000; Türkmen, 2008; Ürey \& diğ., 2017). Farklı araştırma sonuçlarında da kadınların bilim alanında görünürlüğünün az olduğu yönündedir. Ulusal ya da uluslararası düzeyde kullanılan "bilim adamı" kavramı bu etiketlemenin oluşmasında etkilidir (Türk-Eyceyurt \& Tüzün, 2017). Medya bilim insanları hakkında farkındalık yaratmakla birlikte kavram yanılgılarına da neden olmaktadır (Güler\&Akman, 2006). Filmlerde, dizilerde, reklamlarda verilen bilim insanı figürünün erkek olması en çok eleştirilen konuların başında gelmektedir (Boyraz \& Kılıçer, 2017).

$\mathrm{Bu}$ araştırmanın bulguları çerçevesinde bazı çıkarım ve önerilerde bulunulabilir. Bunlar;

1. Öğretmen adayları bilimin doğasına yönelik bazı kavram yanılgılarına sahiptir. Bu kavram yanılgılarının giderilmesine yönelik öğretmen eğitimi kapsamında bilimsel araştırma, bilimin işleyişi, bilimin doğasının etkili şekilde öğretilmesini amaçlayan derslerin programda yer alması gerekir.

2. Bu çalışma Batı Karadeniz Bölgesi'nde yer alan bir üniversitede Sosyal bilgiler öğretmenliği öğrencileriyle gerçekleştirilmiştir. Sosyal bilgiler öğretmen adaylarının bilimsel araştırma ve bilim insanına yönelik algıları belirlenmiştir. Benzer çalışmalar farklı seviyedeki öğrencilerle geçekleştirlebilir. Sonuçlar bu çalışmanın sonuçlarıyla karşılaştırılabilir.

3. Benzer çalışmalar sosyal bilimlerin farklı displinlerinde tarih, coğrafya, felsefe, edebiyat eğitimi alan öğretmen adaylarıyla yapılabilir. Sonuçlar karşılaştırılabilir. Sosyal bilimler alanındaki öğretmen eğitiminde gerekli düzenlemeler yapılabilir.

\section{KAYNAKÇA}

Abd-El-Khalick, F., \& BouJaoude, S. (1997). An exploratory study of the knowledge base for science teaching. Journal of Research in Science Teaching, 34, 673-699.

Abd-El-Khalick, F., Bell, R. L., \& Lederman, N. G. (1998). The nature of science and instructional practice: Making the unnatural natural. Science Education, 82, 417-436.

Ağgül Yalçın, F. (2012). Öğretmen adaylarının bilim insanı imajlarının bazı değişkenlere göre incelenmesi. Ilköğretim Online, 11(3), 611-628. 
Akçay, B. (2011). Turkish elementary and secondary students' views about science and scientist. Asia-Pacific Forum on Science Learning and Teaching, 12(1), 1-11.

Akçay, S. (2016). The analysis of prospective teachers' biotechnology perception through metaphors. Inönü Üniversitesi, Eğitim Fakültesi Dergisi, 17(3), 139-151.

Akerson, V., Abd-El Khalick, F., \& Lederman, N. G. (2000). Influence of a reflective explicit activity-based approach on elementary teachers' conceptions of nature of science. Journal of Research in Science Teaching, 37, 295-317.

Akgün, L. (2012). Bilimsel araştırma dersine ilişkin öğretmen adaylarının algı ve beklentileri. Balıkesir Üniversitesi Sosyal Bilimler Enstitüsü Dergisi, 15(27), 21-30.

Aktamış, H., \& Dönmez, G. (2016). Ortaokul öğrencilerinin fen bilimleri dersine, bilime, fen bilimleri öğretmenine ve bilim insanına yönelik metaforik algıları. Ondokuz Mayıs Üniversitesi Ĕ̆itim Fakültesi Dergisi, 35(1), $7-30$.

American Association for the Advancement of Science. (1989). Science for all Americans. AAAS.

American Assocation for the Advancement of Science. (1990). Project 2061: Science for all Amerians. Oxford University Press.

Angın, D. E., \& Özenoğlu, H. (2019). Öğretmen adaylarının bilim insanına ilişkin algıları. Iğdır Üniversitesi Sosyal Bilgiler Dergisi, 18, 255-276.

Aydın, F., \& Taşar, F. (2010). Fen bilgisi öğretmen adaylarının teknolojinin doğası hakkındaki bilişsel yapıları ve görüşleri. Ahi Evran Üniversitesi Kırşehir Eğitim Fakültesi Dergisi, 11(4), 209-221.

Ayvacı, H. Ş., \& Er Nas, S. (2010). Fen ve teknoloji öğretmenlerinin bilimsel bilginin epistemolojik yapısı hakkındaki temel bilgilerini belirlemeye yönelik bir çalışma. Kastamonu Eğitim Dergisi, 18(3), 691-704.

Balcı, A. (2015). Sosyal Bilimlerde Araştırma (12. Baskı). PegemA Yayıncılık.

Bartan, M. (2019). Okul öncesi öğretmen adaylarının bilim insanı kavramlarına ilişkin metaforik algıları: Kütahya Dumlupınar üniversitesi örneği. Amasya Üniversitesi Eğitim Fakültesi Dergisi, 8(2), 215-239.

Belhan, Ö., \& Laçin Şimşek, C. (2014). Bilim-fen ve teknoloji kulübü’nün öğrencilerin fen ve teknoloji okuryazarlığına ve fene yönelik tutumlarına etkisi. Sakarya Üniversitesi Ĕ̆itim Fakültesi Dergisi, 23(23), 100-120.

Berg, K. E., \& Latin, R. W. (2008). Essentials of research methods in health, physical education, exercise science, and recreation. Wolters Kluwer Health/Lippincott Williams \& Wilkins.

Berg L. B., \& Lune, H. (2015). Sosyal bilimlerde nitel araştırma yöntemleri. (Çev. H. Aydın). Eğitim Yayınevi.

Bıyıklı, C., Başbay, M., \& Başbay, A. (2014). Ortaokul ve lise öğrencilerinin bilim kavramına ilişkin metaforları. Abant İzet Baysal Üniversitesi Ĕ̈itim Fakültesi Dergisi, 14(1), 413-437.

Bilir, V., Eyceyurt Türk, G., \& Tüzün, Ü. (2020). Öğretmen adaylarının kimya alanında çalışan bilim insanı imajları ve bu imajları etkileyen faktörler. Trakya Eğitim Dergisi, 10(1), $76-91$. https://doi.org/10.24315/tred.533849

Bodzin, A., \& Gehringer, M. (2001). Breaking science stereotypes. Science \& Children, 38(4), 36-41.

Boyraz, E., \& Kılıçer, T. (2017). Sırça köşkünde mi, laboratuvarında mi, aramızda mi; nerede bu bilim insanları? Üniversite öğrencilerinin bilim ve bilim insani algısı bir pazarlama sorunu mudur? Süleyman Demirel Üniversitesi Íktisadi ve İdari Bilimler Fakültesi Dergisi, 22(3), 785-806.

Bybee, R. W. (1997). Achieving scientific literacy: From purposes to practices. Heinemann.

Camc1-Erdoğan, S. (2013). Üstün zekâlı ve yetenekli öğrencilerin bilim insanlarına yönelik algıları. Türk Üstün Zekâ ve Ĕgitim Dergisi, 3(1), 13-37.

Chambers, D. W. (1983). Stereotypic images of the scientist: The draw-a-scientist test. Science Education, 67, 255-265.

Chen, S. (2001). Prospective teachers' views on the nature of science and science teaching [Unpublished doctoral dissertation]. Indiana University. 
Creswell, J. W. (2003). Research design: Qualitative, quantitative, and mixed methods approaches. Sage Publications Inc.

Çakıı, Y. (2013). A prerequisite in science education: Understanding nature of science. Marmara Üniversitesi Atatürk Ĕ̈itim Fakültesi Ĕ̈itim Bilimleri Dergisi, 29(29), 57-74.

Çavuş, S. (2010). Illköğretim fen bilgisi ve matematik öğretmenliği lisans öğrencilerinin bilimin doğası hakkındaki görüşlerinin geliştirilmesi [Yüksek lisans tezi]. Abant İzzet Baysal Üniversitesi Sosyal Bilimler Enstitüsü.

Çeliker-Deniş, H., \& Avcı-Erduran, D. (2015). İlkokul öğrencilerinin bilim insanı algılları: öğrencilerin bilimsel faaliyetlere katılması bilim insanı algılarını nasıl etkiler? Mehmet Akif Ersoy Üniversitesi Ĕ̈itim Fakültesi Dergisi, 36, 90-104.

Çepni, S., Bacanak, A., \& Küçük, M. (2003). Fen eğitiminin amaçlarında değişen değerler: Fen-teknoloji-toplum. Değgerler Ĕ̆itimi Dergisi, 1(4), 7-29.

Çetin, G., Huyugüzel Çavaş, P., Palabıyık, E., \& Çavaş, B. (2019). Öğretmen adaylarının bilim ve teknolojiye yönelik algılarının metaforlar yardımıyla ortaya konulması. Necatibey Eğitim Fakültesi Elektronik Fen ve Matematik Ĕ̈itimi Dergisi, 12(2), 1239-1272.

Çermik, H. (2013). Öğretmen adaylarının zihinlerinde canlanan resimdeki bilim insanı. Pamukkale Üniversitesi Eğitim Fakültesi Dergisi, 33(1), 139-153.

Çınar, M., \& Köksal, N. (2013). Sosyal bilgiler öğretmen adaylarının bilime ve bilimin doğasına yönelik görüşleri. Mersin Üniversitesi Eğitim Fakültesi Dergisi, 9(2), 43-57.

Demirbaş, M. (2009). The relationships between the scientist perception and scientific attitudes of science teacher candidates in Turkey: A case study. Scientific Research and Essay, 4(6), 565-576.

Demirkaya, H., \& Çal, Ü. (2018). Sosyal bilgiler öğretmen adaylarının dürüstlük değerine ilşkin meteforik algıları. Ahi Evran Üniversitesi Kırşehir Eğitim Fakültesi Dergisi, 19(3), 1964-1980.

Derman, A., \& Derman, S. (2015). Prospective teachers' metaphorical perceptions on the concept of science. Educational Research and Reviews, 10(2), 161-176.

Dikmenli, M. (2010). Undergraduate biology students' representations of science and the scientist. College Student Journal, 44(2), 579-588.

Doğan, H. (2015). Farklı ülkelerden 11-13 yaş aralığındaki öğrencilerin bilim ve bilim insanı hakkındaki görüşleri [Yayımlanmamış yüksek lisans tezi]. Akdeniz Üniversitesi Eğitim Bilimleri Enstitüsü.

Dogan, N., \& Abd-El-Khalick, F. (2008). Turkish grade 10 students' and science teachers' conceptions of nature of science: A national study. Journal of Research in Science Teaching, 45(10), 1083-1112.

Finson, K. D. (2002). Drawing a scientist: What we do and do not know after fifty years of drawings. School Science and Mathematics, 102, 335-346.

Gay, L. R., Mills, G. E., \& Airasian, P. (2009). Educational research: Competencies for analysis and applications (9th ed). Pearson.

Goodrum, D., Hackling, M., \& Rennie, L. (2000). The status and quality of teaching and learning of science in Australian schools: A research report. Department of Education, Training and Youth affairs.

Gürgil, F. (2018). A study on social studies teacher candidates' perception of science, scientific research and scientists. International Journal of Progressive Education, 14(3), 140-159.

Harman, G., \& Şeker, R. (2019). Fen bilgisi öğretmen adaylarının fizik, kimya ve biyoloji deneylerine yönelik algılarının metaforlar aracılığı ile incelenmesi. Manisa Celal Bayar Üniversitesi Sosyal Bilimler Dergisi, 17(1), 153-174.

Kalaycı, S. (2018). İlkokul öğrencilerinin “bilim” ve "fen bilimleri dersi” kavramlarına yönelik algılarının metafor yoluyla belirlenmesi. Uluslararası Sosyal ve Eğitim Bilimleri Dergisi, 5(9), 1-21.

Kara, B. (2013). Ortaokul (5.6.7 ve 8. sınıf) ögrencilerinin bilim insanına yönelik tutum ve imajının belirlenmesi [Yayınlanmamış yüksek lisans tezi]. Erciyes Üniversitesi. 
Kara, B., \& Akarsu, B. (2015). Ortaokul öğrencilerinin bilim insanına yönelik tutum ve imajının belirlenmesi. Fen Ĕgitimi ve Araştırmaları Derneği Fen Bilimleri Öğretimi Dergisi, 3(2), 90-116.

Karaçam, S., Aydın, F., \& Digilli, A. (2014). Fen ders kitaplarında sunulan bilim insanlarının basmakalıp bilim insanı imajı açısından değerlendirilmesi. Ondokuz Mayıs Üniversitesi Eğitim Fakültesi Dergisi, 33(2), 606-627.

Kaya, O. N., Doğan, A., \& Öcal, E. (2008). Turkish elementary school students' images of scientists. Eurasian Journal of Educational Research, 32, 83-100.

Kemaneci, G. (2012). Üstün yetenekli ögrencilerin bilim insanı hakkındaki imajlarının araştırılması [Yayınlanmamış yüksek lisans tezi]. Gazi Üniversitesi Eğitim Bilimleri Enstitüsü.

Keser, F. F. (2012). Üstün yetenekli ögrrencilerin bilim ve bilim insanına yönelik görüşlerinin ve bu görüşleri etkileyen faktörlerin belirlenmesi [Yayınlanmamış yüksek lisans tezi]. Gazi Üniversitesi Eğitim Bilimleri Enstitüsü.

Kıral, B. (2017). Eğitim fakültesi öğrencilerinin bilim insanına bakış açısı. Uluslararası Sosyal Araştırmalar Dergisi, 10(52), 773-782.

Kibar Kavak, G. (2008). Öğrencilerin bilime ve bilim insanına yönelik tutumların ve imajlarını etkileyen faktörler [Yayınlanmamış Yüksek Lisans Tezi]. Selçuk Üniversitesi.

Korkmaz, H., \& Kavak, G. (2010). İlköğretim öğrencilerinin bilime ve bilim insanına yönelik imajları. İlköğretim Online, 9(3), 2-26.

Köksal, M. S., \& Şahin, C. T. (2014). Understandings of advanced students on nature of science and their motivational status to learn nature of science: A Turkish case. Journal of Baltic Science Education, 13(1), $46-58$.

Köksal, N., \& Çınar, M. (2012). Sosyal bilgiler öğretmen adaylarının bilimin doğasına ve öğrenmeöğretme sürecine yansitılmasına ilişkin görüşleri. Pamukkale Üniversitesi Sosyal Bilimler Enstitüsü Dergisi, 11, 191-203.

Kösem, Ş. (2017). Metafofic perspectives of teacher candidates in science and technology. Uluslararası Avrasya Sosyal Bilimler Dergisi, 8(28), 1-20.

Köseoğlu, F., Tümay, H., \& Üstün, U. (2010). Bilimin doğası öğretimi mesleki gelişim paketinin geliştirilmesi ve öğretmen adaylarına uygulanması ile ilgili tartışmalar. Ahi Evran Üniversitesi Kırşehir Eğitim Fakültesi Dergisi, 11(4), 129-162.

Küçük, M., \& Bağ, H. (2012). 4 ve 5. sınıf öğrencilerinin bilim insanı imajlarının karşılaştırılması. Bayburt Üniversitesi Eğitim Fakültesi, 7(2), 125-138.

Küçükoğlu, A., Taşgın, A., \& Çelik, N. (2014). Öğretmen adaylarının bilimsel araştırma sürecine ilişkin görüşleri üzerine bir inceleme. Türkiye Sosyal Araştırmalar Dergisi, 173(173), 11-24.

Labuschagne, A. (2003). Qualitative research: Airy fairy or fundamental? The qualitative report, 8(1). Şubat 1, 2021 tarihinde http://www.nova.edu/ssss/QR/QR8-1/labuschagne.html adresinden erişilmiştir.

Lederman, N. (2006). Research on nature of science: Reflections on the past, anticipations of the future. AsiaPacific Forum on Science Learning and Teaching, 7(1), 1-11.

Losh, S. C., Wilke, R., \& Pop, M. (2008). Some methodological issues with "Draw a Scientist Tests" among young children. International Journal of Science Education, 30(6), 773-792.

Medina-Jerez, W., Middleton, K. V., \& Rabaza-Orihuela, W. (2011). Using the DAST-C to explore Colombian and Bolivian students' images of scientists. International Journal of Science and Mathematics Education, 9, 657-690.

Milli Eğitim Bakanlığı. (2018). Sosyal bilgiler dersi ögretim programı. Ekim 1, 2020 tarihinde http://mufredat.meb.gov.tr/Dosyalar/201812103847686SOSYAL\%20B\%C4\%B0LG\%C4\%B0LER\%20\%C3\%96\%C4\%9ERET\%C4\%B0M\%20PROGRAMI \%20.pdf adresinden edinilmiştir.

National Research Council. (1996). National science education standards. National Academy Press.

National Research Council. (2004). How people learn: Bridging research and practice. National Academy Press. 
National Standarts for Social Studies. (2010). The themes of social studies. Ekim 1, 2020 tarihinde http://www.socialstudies.org/standards/strands, adresinden edinilmiştir.

National Standarts for Social Studies. (2019). National curriculum standards for social studies: Introduction. Ekim 1, 2020 tarihinde https://www.socialstudies.org/standards/introduction adresinden edinilmiştir.

Özkan, B., Özeke, V., Güler, G., \& Şenocak, E. (2017). Üniversite öğrencilerinin bilim insanı imajları ve bu imajları etkileyen bazı faktörler. Erzincan Üniversitesi Eğitim Fakültesi Dergisi, 19(1), 146-165.

Özgün, B., Gürkan, G., \& Kahraman, S. (2018). Öğretmen adaylarının bilim ve bilim insanı kavramlarına ilişkin algılarının metafor analizi aracılığıyla incelenmesi. Inönü Üniversitesi Eğitim Fakültesi Dergisi, 19(2), 204-225.

Özsoy, S., \& Ahi, B. (2014). Images of scientists through the eyes of the children. Necatibey Eğitim Fakültesi Elektronik Fen ve Matematik Eğitimi Dergisi (EFMED), 8(1), 204-230.

Patton, M. Q. (2002). Qualitative research and evaluation methods (3rd ed.). Sage Publications, Inc.

Ragin, C. C. (1994). Constructing social research. Pine Forge.

Read, S. T., Toye, C., \& Wynaden, D. (2016). Experiences and expectations of living with dementia: A qualitative study. Collegian.

Rubin, E., Bar, V., \& Cohen, A. (2003). The images of scientists and science among Hebrew- and Arabic-speaking pre-service teachers in Israel. International Journal of Science Education, 25(7), 821-846.

Ruiz-Mallén, I., \& Escalas, M. T. (2012). Scientists seen by children a case study in Catalonia, Spain. Science Communication, 34(4), 520-545.

Ryan, A. G., \& Aikenhead, G. S. (1992). Students' preconceptions about the epistemology of science. Science Education, 76, 559-580.

Saban, A. (2004). Giriş düzeyindeki sınıf öğretmeni adaylarının “öğretmen” kavramına ilişkin ileri sürdükleri metaforlar. Türk Ĕ̈itim Bilimleri Dergisi, 2(2), 131-155.

Saban, A. (2007). Lisansüstü öğrencilerin nitel araştırma metodolojisine ilişkin algıları. Selçuk Üniversitesi Sosyal Bilimler Enstitüsü Dergisi, 17, 469-485.

Samaras, G., Bonoti, F., \& Christidou, V. (2012). Exploring children's perception of scientists through drawings and interviews. Procedia-Social and Behavioral Sciences, 46, 1541-1546.

Saraç, E., \& Capellaro, E. (2015). Sınıf öğretmenleri ve sınıf öğretmen adaylarının bilimin doğasına ilişkin görüşleri. Mediterranean Journal of Humanities, 2, 331-349.

Sezen Vekli, G., Çilsalar Sagnak, H., \& Yaman, F. (2020). TÜBİTAK 4004 doğa lab: Doğada sorgulama temelli bilim projesinin bilim insanı imaj ve görüşlerine etkisi. Abant İzet Baysal Üniversitesi Eğitim Fakültesi Dergisi, 20(1), 149-167. https://doi.org/10.17240/aibuefd.2020.20.52925-537875

Shenton, A. (2004). Strategies for qualitative research projects. Education for Information, 22, 63-75.

Sönmez, V., \& Alacapınar, F. G. (2011). Örneklendirilmiş bilimsel araştırma yöntemleri. Anı Yayınları.

Şenel, T., \& Aslan, O. (2014). Okul öncesi öğretmen adaylarının bilim ve bilim insanı kavramlarına ilişkin metaforik algıları. Mersin Üniversitesi Eğitim Fakültesi Dergisi, 10(2), 76-95.

Tairab, H. H. (2001). How do pre-service and in-service science teachers view the nature of science and technology? Research in Science and Technological Education, 19(2), 235-250.

Taşdemir, M., \& Taşdemir, F. (2016). Öğretmen adaylarının bilimsel araştırma kavramına yükledikleri metaforlar. Ahi Evran Üniversitesi Kırşehir Ë̆itim Fakültesi Dergisi, 17(1), 419-438.

Terzi, A. R. (2005). Üniversite öğrencilerinin bilimsel epistemolojik inançları üzerine bir araştırma. Afyon Kocatepe Üniversitesi Sosyal Bilimler Dergisi, 7(2), 298-311.

Toğrol, A. (2000). Öğrencilerin bilim insanı ile ilgili imgeleri. Eğitim ve Bilim, 25(118), 49-56.

Topçu, E., \& Karatekin, K. (2017). Sosyal bilgiler ders kitaplarında bilim adamları. Kastamonu Eğitim Dergisi, $25(6), 2127-2152$. 
Türk-Eyceyurt, G., \& Tüzün, Ü. N. (2017). Lise öğrencilerinin bilim insanı imajları ve bilimin doğası mitleri. Ahi Evran Üniversitesi Kırşehir Eğitim Fakültesi Dergisi (KEFAD), 18(2), 19-36.

Türkmen, H. (2008). Turkish primary students' perceptions about scientist and what factors affecting the image of the scientist. Eurasia Journal of Mathematics, Science and Technology Education, 4(1), 55-61.

Uslu, N., Kocakülah, A., \& Gür, H. (2016). Ortaokul öğrencilerinin bilim, bilim insanı ve öğretmen kavramlarına ilişkin metafor algılarının incelenmesi. Ĕgitim ve Öğretim Araştırmaları Dergisi, 5(1), 354-364.

Ürey, M., Karaçöp, A., Göksu, V., \& Çolak, K. (2017). Fen ve sosyal bilimler kökenli öğretmen adaylarının bilim insanı algıları. YYÜ Ĕ̈itim Fakültesi Dergisi, 1(14), 205-226.

Yakmaci, B. (1998). Science (biology, chemistry and physics) teachers' views on the nature of science as a dimension of scientific literacy [Unpublished master's thesis]. Boğaziçi University.

Yalçın, F. A. (2012). Investigation of prospective teachers' image of scientist with respect to some variable. Illkögretim Online, 11(3), 611-628.

Yenice, N., Özden, B., \& Balcı, C. (2015). Fen bilgisi ve sınıf öğretmeni adaylarının bilimin doğasına yönelik görüşlerinin incelenmesi. Erzincan Üniversitesi Eğitim Fakültesi Dergisi, 17(1), 237-281. https://doi.org/10.17556/jef.52022

Yıldırım, A., \& Şimşek, H. (2011). Sosyal bilimlerde nitel araştırma yöntemleri. Seçkin Yayıncılık.

Yontar Toğrol, A. (2013). Turkish students' images of scientists. Journal of Baltic Science Education, 12(3), 289298.

Zorlu, Y., \& Baykara, O. (2015). Teknoloji bilimin uygulaması mıdır? Fen ve teknoloji öğretmen adaylarının görüşleri. Atatürk Üniversitesi Kazım Karabekir Eğitim Fakültesi Dergisi, 0 (29), 123-144. 


\section{EXTENDED ABSTRACT}

\section{The Metaphorical Perceptions Of Social Studies Teacher Candidates On Scientific Research And Scientist}

\section{Introduction}

One of the important goals of the restructuring efforts in education that has been going on for many years is to raise individuals with scientific literacy (American Association for the Advancement of Science [AAAS], 1989, 1990; National Research Council [NRC], 1996, 2004; National Science Education Standards [NCSS], 2010, 2019). Raising citizens with scientific literacy in the society and preparing them for social life is also included in the aims of national education (MoNE, 2018). Educating scientifically literate individuals will be possible by structuring teaching environments for students' perception of the nature of science at an adequate level, knowledge of scientific research, and development of scientific knowledge (Abd-El-Khalick et al., 1998; Lederman \& Lederman, 2004). The perception of "who the scientist is and what roles he/she takes", which is part of the nature of science, also becomes important. In particular, during the undergraduate education period, where professional knowledge is gained, the education received by teacher candidates stands out in terms of scientific research and scientist perceptions. In the literature, there are studies conducted to determine the metaphorical perceptions of teacher candidates on scientific research and scientists (Bartan, 2019; Çetin et al., 2019; Harman \& Şeker, 2019; Kösem, 2017; Özgün et al., 2018; Taşdemir \& Taşdemir, 2016). Few studies have been found to determine the perceptions of social studies teacher candidates on scientific research (Çal \& Demirkaya, 2018; Ürey et al., 2017). The purposes of these studies were not directly to determine the perceptions of social studies teacher candidates on scientific research and scientists, but to compare their perceptions of science and scientists with other fields or to determine their metaphorical perceptions of scientific value.

The following questions were tried to be answered in this study, which aimed to determine the metaphorical perceptions of social studies teacher candidates on scientific research and scientists:

1. What are the metaphors that social studies teacher candidates have for the concept of scientific research?

2. What are the metaphors that social studies teacher candidates have for the concept of a scientist?

3. What are the scientist images that social studies teacher candidates have?

\section{Method}

The study was carried out using phenomenology research design, one of the qualitative research approaches, in order to determine the metaphorical perceptions of social studies teacher candidates on scientific research and scientists. The study was carried out with year 1,2,3 and 4 teacher candidates (145 students) studying in the department of social studies teaching. As a data collection tool, in the first part, the questions about determining the demographic characteristics of the participants, in the second part, sentence patterns such as "Scientific research is like... because...." and "Scientist is like ....., because ....." in the semi-structured 
form (Akçay, 2016; Saban, 2004) and the "Draw-A-Scientist Test" developed by Chambers (1983) were used. The data was analyzed using the content analysis method.

\section{Result}

As research findings, social studies teacher candidates were found to form a total of 227 different metaphors under seven different categories: Method, characteristics of the nature of science, and misconceptions for the concept of "scientific research" personal characteristics, occupational characteristics, occupational environment and tools used, and model scientist for the concept of "scientist". The teacher candidates created a total of 119 metaphors in the categories of method, nature of science, and errors for the concept of "scientific research". The teacher candidates formed a total of 108 metaphors for the concept of "scientist" in the categories of personal characteristics, occupational characteristics, occupational environment, and tools they use.

\section{Discussion}

The teacher candidates created metaphors in the categories of method, nature of science, and errors for the concept of "scientific research". The method category includes metaphorical statements based on research and aimed at the purpose. The teacher candidates have defined scientific researches as method-based studies aimed at finding the truth. Positive and largely concrete metaphors on science and scientific research concepts have been observed to be formed by the teacher candidates in the studies conducted in the literature.

There were metaphorical expressions about the changeable, cumulative, limitless, and multidimensional nature of science in the category of characteristics of the nature of science. There are studies carried out with different sample groups in the literature about the changeable nature of science.

In this study, teacher candidates' existing perceptions on the concept of scientific research were determined to be accurate. However, it has been found that candidate teachers had some misconceptions about scientific research. These errors have been identified as confusing science with technology, the error that science is conclusive, and single method error in science.

Teacher candidates' perceptions of the scientist concept were determined to be personal characteristics, occupational characteristics, occupational environment, and tools they use. Teacher candidates described the personal characteristics of the scientist as a hardworking, researcher, intelligent and curious. Scientists that teacher candidates see as models were Canan Dağdeviren, Aziz Sancar, Newton, Einstein, and İlber Ortaylı. Teacher candidates have often portrayed the materials used by scientists as laboratory materials.

"International Journal of New Approaches in Social Studies - IJONASS" is licensed under a Creative Commons Attribution-NonCommercial-ShareAlike 4.0 International License. 